medRxiv preprint doi: https://doi.org/10.1101/2021.12.01.21267124; this version posted December $2,2021$. The copyright holder for this preprint (which was not certified by peer review) is the author/funder, who has granted medRxiv a license to display the preprint in

All rights reserved. No reuse allowed without permission.

\title{
Neuropsychiatric, cognitive and brain morphology characteristics of conversion from Mild
}

\section{Cognitive Impairment to Alzheimer's Disease}

Ronat Lucas ${ }^{\mathrm{a}, \mathrm{b}}$, Hanganu Alexandru, ${ }^{\mathrm{a}, \mathrm{c}}$, for the ADNI group*,

${ }^{a}$ Centre de Recherche de l'Institut Universitaire de Gériatrie de Montréal, Montréal, Québec, Canada

bFaculté de Médecine, Département de Médecine, Université de Montréal, Québec, Canada

'Faculté des Arts et des Sciences, Département de Psychologie, Université de Montréal, Québec,

Canada

*Alzheimer's Disease Neuroimaging Initiative

Corresponding Author:

Alexandru Hanganu, M6828, 4545 ch. Queen Mary, H3W 1W6, Montréal, QC

Telephone: (514) 340-3540 \#4897

E-mail: alexandru.hanganu@ umontreal.ca

Running title : Neuropsychiatric symptoms and MRI predict Alzheimer's Disease 
medRxiv preprint doi: https://doi.org/10.1101/2021.12.01.21267124; this version posted December $2,2021$. The copyright holder for this preprint (which was not certified by peer review) is the author/funder, who has granted medRxiv a license to display the preprint in

All rights reserved. No reuse allowed without permission.

\begin{abstract}
:
The impact of neuropsychiatric symptoms (NPS) on cognitive performance has been extensively reported, and this impact was better defined in the aging population. Yet a potential impact of NPS on brain morphology, cognitive performance and interactions between them in a longitudinal setting, as well as the potential of using these values as prediction of conversion - have remained questionable. We studied 156 participants with mild cognitive impairment (MCI) from the Alzheimer's Disease Neuroimaging Initiative database who maintained the same level of cognitive performance after a 4year follow-up and compared them to 119 MCI participants who converted to dementia. Additionally, we assessed the same analysis in 170 healthy controls who remained healthy at follow-up. Compared to 15 controls who converted to MCI. Their neuropsychological, neuropsychiatric, and brain morphology data underwent statistical analyses of 1) baseline comparison between the groups; (2) analysis of covariance model controlling for age, sex, education, and MMSE score, to specify the cognitive performance and brain structures that distinguish the two subgroups, and 3) used the significant ANCOVA variables to construct a binary logistic regression model that generates a probability equation for a given individual to convert to a lower cognitive performance state.

Results showed that MCI who converted to AD in comparison to those who did not convert, exhibited a higher NPS prevalence, a lower cognitive performance and a higher number of involved brain structures. Furthermore, agitation, memory and the volumes of inferior temporal, hippocampal and amygdala sizes were significant predictors of MCI to AD conversion.
\end{abstract}

Keywords: Neuropsychiatry, cognitive performance, cognitive decline, MRI 
medRxiv preprint doi: https://doi.org/10.1101/2021.12.01.21267124; this version posted December $2,2021$. The copyright holder for this preprint (which was not certified by peer review) is the author/funder, who has granted medRxiv a license to display the preprint in All rights reserved. No reuse allowed without permission.

\section{Clinical states of age-related cognitive decline}

Current clinical evaluations of cognitive decline include only two stages: (a) the mild cognitive impairment (MCI) and (b) dementia (or major cognitive impairment). These stages are based on cognitive markers (APA 2013; Jak et al. 2009; Albert et al. 2011) that are evaluated with comprehensive neuropsychological assessments. One of the leading clinical presentations of dementia is the Alzheimer's disease (AD) type (Heidebrink 2002). An MCI level that would lead to AD has been characterized by either subjective concern about a change in cognition, or a lower performance in one or more cognitive domains in comparison to those expected for the patient's age and educational background, without significant impairment in social or occupational functioning (Albert et al. 2011). The condition of reduced cognitive performance induces the existence of MCI single or multi-domain (Csukly et al. 2016; Petersen \& Negash 2008).

On the other hand, in the demented state, cognitive deficits are sufficiently extensive that the individual is no longer able to carry out his or her daily life tasks alone or without supervision. These cognitive stages are frequently accompanied by psychological suffering for patients, relatives and caregivers (Bednarek et al. 2016; Schulz et al. 2008) as well as psychological and behavioral disturbances called neuropsychiatric symptoms (NPS)(Cummings et al. 1994).

\section{Neuropsychiatric symptoms in cognitive decline}

Most of NPS are clearly observed in dementia (Cummings et al. 1994), but they also occur in the MCI stage (Rosenberg et al. 2013) and can be present in cognitively healthy individuals (Mortby et al. 2018). NPS presence was shown to increase the risk of AD in MCI (Teng et al. 2007). Indeed, these NPS are found in the cognitively normal $(\mathrm{CN})$ population (Geda et al. 2004; Geda et al. 2008; Mortby et al. 2018), and their prevalence increases with the advancement of clinical stages: it is higher in the MCI population and even higher in the AD population (Geda et al. 2004). Also, they may increase the likelihood of MCI progressing into AD (Teng et al. 2007) and thus increase the likelihood of developing dementia (Rosenberg et al. 2013). These include depression (Lee et al. 2012; Steenland et al. 2012), apathy (van Dalen et al. 2018) and anxiety (Rozzini et al. 2009; Gallagher et al. 2011) (cited by Ma 2020), but the latter is more controversial (Robert et al. 2008; Devier et al. 2009). However, the impact of depression on cognitive decline is greater in MCI than in AD (Lee et al. 2019). 
medRxiv preprint doi: https://doi.org/10.1101/2021.12.01.21267124; this version posted December $2,2021$. The copyright holder for this preprint (which was not certified by peer review) is the author/funder, who has granted medRxiv a license to display the preprint in All rights reserved. No reuse allowed without permission.

In addition, several studies have looked at longitudinal follow-ups of participants and patients with NPS. For example, the study by Moon et al (2017) confirms a greater progression from MCI to AD in patients with depressive symptoms according to the amyloid status of MCI patients: the study is based on the analysis of longitudinal ADNI data and shows, in MCI patients with amyloid-positive amyloid and depression, a higher rate of $\mathrm{AD}$ conversion than patients without depression. In addition, cognitive decline is accelerated over the 2-year follow-up period. Also based on the ADNI database, Zahodne et al. (2013) studied the atrophy pathways of MCI subjects with and without depression and apathy on a longitudinal level. Their results show that depression is associated with greater baseline entorhinal atrophy and accelerated anterior cingulate atrophy. To our knowledge, fewer studies have looked at the factors of conversion from normal cognition to $\mathrm{MCI}$ and the course of cognitive decline in healthy individuals. However, these studies were able to highlight that healthy individuals with mild behavioral impairment exhibited greater attentional and working memory decline after one year of follow-up (Creese et al. 2019). Also, the presence of NPS, including depression, apathy, and anxiety, is also associated with faster global and domain-specific decline (Burhanullah et al. 2020; Krell-Roesch et al. 2021). In addition, MRI data were also exploited as predictors of conversion from MCI to AD. Thus, it has been shown that MCI that convert to $\mathrm{AD}$ have reduced volumes in the medial temporal lobe (hippocampus, amygdala, and entorhinal cortex), the insular, posterior cingulate, precuneus and orbitofrontal cortex (Davatzikos et al. 2011; deToledo-Morrell et al. 2004; Risacher et al. 2009). However, these data do not appear to have been addressed in the conversion from CN to MCI. This shows the importance of screening for NPS and to more investigate MRI in CN subjects.

Fort his study, we hypothesized that (1) participants who convert to a lower cognitive performance state would exhibit increased variation in NPS; (2) these variations would be associated with brain morphology and cognitive performance, and (3) these correlations can be used to predict the conversion.

\section{Materials and Methods}

\section{Participants}

275 patients with MCI and 185 cognitively normal participants $(\mathrm{CN})$ from the ADNI database were extracted. Data used in the preparation of this article were obtained from the ADNI database 
medRxiv preprint doi: https://doi.org/10.1101/2021.12.01.21267124; this version posted December $2,2021$. The copyright holder for this preprint (which was not certified by peer review) is the author/funder, who has granted medRxiv a license to display the preprint in All rights reserved. No reuse allowed without permission.

(adni.loni.usc.edu). The ADNI, launched in 2003 and led by Principal Investigator Michael W. Weiner, $\mathrm{MD}$, has for main objective to understand the progression of $\mathrm{MCI}$ and early $\mathrm{AD}$ by combining imaging, biological and neuropsychological data (Mueller et al. 2005; Shaw et al. 2007) (http://www.adniinfo.org/). Entry criteria for patients with amnestic MCI include a Mini-Mental State Examination score of 24 to 30 and a Memory Box score of at least 0.5 , whereas other details on the ADNI cohort can be found online. All patients with $\mathrm{AD}$ met National Institute of Neurological and Communication Disorders/Alzheimer's Disease and Related Disorders Association criteria for probable AD with a MiniMental State Examination score between 20 and 26, a global Clinical Dementia Rating of 0.5 or 1, a sum-of-boxes Clinical Dementia Rating of 1.0 to 9.0, and, therefore, are only mildly impaired. Exclusion criteria included any serious neurological disease other than possible $\mathrm{AD}$, any history of brain lesions or head trauma, or psychoactive medication use (including antidepressants, neuroleptics, chronic anxiolytics, or sedative hypnotics).

Retained participants had completed a neuropsychiatric examination, a comprehensive neuropsychological assessment and a 3 Tesla MRI. The clinical status was available until 4-years follow-up for all participants. Based on the clinical stage at follow-up, four groups were created in order to distinguish participants who converted to a worse cognitive performance compared to those that maintained their previous cognitive level. Our groups consisted of: $156 \mathrm{MCI}$ remained MCI at followup (MCI-non-converted), $119 \mathrm{MCI}$ participants that converted to AD (MCI-converted), $170 \mathrm{CN}$ both at baseline and at follow-up (CN-non-converted) and $15 \mathrm{CN}$ that converted to $\mathrm{MCI}(\mathrm{CN}$-converted) (Table $1)$.

\section{Data acquisition and processing}

The neuropsychiatric changes were evaluated using the Neuropsychiatric Inventory (Cummings et al. 1994). The inventory consists of the evaluation of the presence, severity and frequency of 12 neuropsychiatric symptoms (NPS): delusions, hallucinations, agitation/aggressiveness, depression, anxiety, euphoria, apathy, disinhibition, irritability, aberrant motor behaviors, nighttime behaviors and appetite changes. We included the evaluations performed by the participants' relatives and only the prevalence of each NPS is considered. 
medRxiv preprint doi: https://doi.org/10.1101/2021.12.01.21267124; this version posted December $2,2021$. The copyright holder for this preprint (which was not certified by peer review) is the author/funder, who has granted medRxiv a license to display the preprint in

All rights reserved. No reuse allowed without permission.

Neuropsychological assessment was based on the tests assessing: (1) anterograde verbal memory (Rey Auditory Verbal Learning Test - RAVLT), (2) focused attention (Trail Making Test A - TMTA), (2) processing speed (Wechsler Adult Intelligence Scale Code subtest), (3) mental flexibility (Trail Making Test B - TMTB), (4) visuoconstructive planning (clock test), (5) working memory (digit span), (6) semantic lexical evocation (animal and vegetable fluency) and (7) oral naming (Boston Naming Test BNT). Moreover, the Mini-Mental State Examination score was used as a demographic factor of global cognitive efficiency.

MRI structural images were processed with FreeSurfer 7.1.1 software, on Linux Centos 7 on ComputeCanada environment, cluster Cedar and managed with our in-house pipeline (github.com/alexhanganu/nimb) that allowed automated exclusion of post-processed data with errors as well as extraction of statistical data, diminishing potential human error. Cortical thickness parameter was extracted based on the Destrieux et al. atlas (2010) while subcortical volumes were extracted for all regions as well as sub-regional based on the corresponding atlases; for the thalamus (Iglésias et al. 2018), amygdalas (Saygin et al. 2017), and hippocampi (Iglésias et al. 2015). The volumes of subcortical structures were corrected with the estimated Total Intracranial Volume (eTIV) (Sanfilipo et al. 2002).

\section{Statistical analysis}

The statistical analyses are based on the methodology of Orso et al. (2020). For this study, the data were analyzed using SPSS version 26.0 software. Descriptive analyses verified the similarity of the groups (MCI-converted vs. MCI-non-converted; CN-converted vs. CN-non-converted) in terms of age, years of education, MMSE score and sex distribution (respectively mean comparisons by Student test and contingency $\mathrm{Chi}^{2}$ analysis). Statistical analysis consisted of three steps. (I) First, the groups were compared based on (i) means of cognitive performances (Two sample t-tests), (ii) prevalence of NPS (Chi ${ }^{2}$ tests) and (iii) means of neuroimaging structure sizes (Student t-tests of cortical thickness and subcortical volumes). (II) Features that were shown to be significant in the first three comparisons, were included in the Analysis of Covariance Model with age, sex, years of education and MMSE score as covariates. (III) Finally, features that were deemed significant in the ANCOVA model were imputed in 
medRxiv preprint doi: https://doi.org/10.1101/2021.12.01.21267124; this version posted December $2,2021$. The copyright holder for this preprint (which was not certified by peer review) is the author/funder, who has granted medRxiv a license to display the preprint in

All rights reserved. No reuse allowed without permission.

a two binary logistic regression model to generate probability equations for $\mathrm{AD}$ and $\mathrm{MCI}$ conversion based on neuropsychiatric, cognitive and neuroimaging data.

\section{Results}

Demographical, neuropsychiatric and neuropsychological differences

At baseline, in comparison to MCI-non-converted, the MCI-converted group had a lower MMSE score, worse performance on some cognitive tests (clock test, RAVLT immediate recall A and B, RAVLT delayed recall, semantic lexical evocation for "vegetables", TMT A and B, WAIS code) and a significantly higher prevalence of agitation and appetite changes (Table 1).

On the other hand, the $\mathrm{CN}$-converted and $\mathrm{CN}$-non-converted groups showed similar results regarding age, years of education, gender distribution, MMSE score as well as distributions of neuropsychiatric symptoms. Several significant differences were depicted in the cognitive performance at baseline, with the $\mathrm{CN}$-converted group having a worse performance in comparison to $\mathrm{CN}$-nonconverted on RAVLT 2nd recall, digit span backward and semantic lexical evocation of "vegetables".

\section{Brain morphology differences}

In terms of brain morphology, the MCI-converted group also showed multiple significant difference in comparison to the MCI-non-converted one. Significant changes were depicted in all brain lobes both on the cortical level in gyri and sulci as well as regarding the volumes of subcortical structures, notably the volumes of hippocampus, amygdala and thalamus subregions (Supplementary table 1).

By contrast, the $\mathrm{CN}$-converted group, when compared to the $\mathrm{CN}$-non-converted one, showed a smaller number of brain morphological changes. Specific differences were found in the frontal inferior orbital gyrus and suborbital sulcus, cingulate ventral posterior gyrus, temporal pole and temporal middle gyrus. CN-converted also had reduced volumes in some hippocampal subregions (tails, subiculum, presubiculum, molecular layer, CA1 body), amygdala and thalamic subregions (central lateral, pulvinar anterior nuclei, pulvinar medial nuclei, paratenial nucleus) (Supplementary table 2). 
medRxiv preprint doi: https://doi.org/10.1101/2021.12.01.21267124; this version posted December $2,2021$. The copyright holder for this preprint (which was not certified by peer review) is the author/funder, who has granted medRxiv a license to display the preprint in All rights reserved. No reuse allowed without permission.

Concerning cognitive performance, in MCI to AD conversion, ANCOVA shows a significant lower performance in MCI-converted for every score of the RAVLT, and on semantic lexical evocation "vegetables" than in MCI-non-converted and lower performance in patients with appetitive changes for the 2nd free recall of the RAVLT. Only one interaction was found with agitation on the recall of the Blist of the RAVLT (non-converted with agitation perform better than those without while the opposite trend is present in converted). By contrast, the $\mathrm{CN}$-converted group, when compared to the $\mathrm{CN}$-nonconverted one, exhibited significative lower performance on the 2nd recall of the RAVLT, and in semantic lexical evocation of "vegetables" (Supplementary table 4).

Regarding brain structures, most of the structures (all lobes, hippocampi and amygdala) were smaller in MCI-converted in relation to MCI-non-converted whereas agitation was featured by greater cortical thicknesses (frontal, parietal, occipital, temporal) and subcortical volumes (hippocampus and amygdala). In contrast, patients with appetite changes had precentral thinning and larger hippocampus and amygdala volumes than those without (Supplementary Table 3). Also, there was an interaction effect between conversion to $\mathrm{AD}$ and agitation on the occipital, cingulate, parietal and precentral structures. Agitation in MCI-converted patients is featured by: larger structure in occipital lobe and smaller left subcallosal gyrus and parieto-occipital sulcus; whereas a greater inferior precentral thinning in MCI-non-converted than converted was found. Interaction between conversion and appetite changes show that converted patients with appetite changes had smaller for occipital and parietal structures than patients without. The reverse pattern was found in non-converted patients (Supplementary table 3). In $\mathrm{CN}$-converted, the previous structures (Supplementary table 2) remained significantly smaller than in $\mathrm{CN}$-non-converted, except for the central lateral and paratenial thalamic nuclei (Supplementary table 4).

\section{Prediction of $A D$ from $M C I$ and $M C I$ from $C N$ based on logistic regression}

Binary logistic regression models (Tables 2,3) based on the significant results of the ANCOVA models provided probabilistic prediction equations for conversion of $\mathrm{CN}$ participants to $\mathrm{MCI}$ and MCI patients to $\mathrm{AD}$.

The probability equation for an MCI participant to convert to $\mathrm{AD}$ is as follows: $\mathrm{P}(\mathrm{AD})=1 /\left(1+\mathrm{e}^{-\left[-0,070 * \mathrm{X}_{1}\right.}{ }^{-}\right.$ $0,275 * \mathrm{X}_{2}-0,233 * \mathrm{X}_{3}+0,765 * \mathrm{X}_{4}-2,425 * \mathrm{X}_{5}-4,026 * \mathrm{X}_{6}-10665.677 * \mathrm{X}_{7}-26915.115 * \mathrm{X}_{8}-18399,454 * \mathrm{X}_{9}+28.139$ ) where $\mathrm{e}=2,71828$ (the base of 
medRxiv preprint doi: https://doi.org/10.1101/2021.12.01.21267124; this version posted December $2,2021$. The copyright holder for this preprint (which was not certified by peer review) is the author/funder, who has granted medRxiv a license to display the preprint in All rights reserved. No reuse allowed

natural logarithm), $X_{1}=$ Age, $X_{2}=$ the RAVLT $1^{\text {st }}$ immediate recall score, $X_{3}=$ the RAVLT $5^{\text {th }}$ immediate recall score, $X_{4}=$ the presence of agitation, $X_{5}=$ the left precuneus gyrus thickness, $X_{6}=$ the right inferior temporal sulcus thickness, $X_{7}=$ the right hippocampal tail volume, $X_{8}=$ the left hippocampal fimbria volume, $\mathrm{X}_{9}=$ the left amygdala accessory basal nucleus volume and 28.139 is the model's constant. The model had a sensitivity of $72.3 \%$, specificity of $82.1 \%$ (Tables 3 ), positive and negative predictive value of $75.44 \%$ and $79.5 \%$ and Yule Q coefficient ([true positives*true negatives - false positives*false negatives] / [true positives*true negatives + false positives*false negatives]) was 0.85 , indicating a very strong link between the diagnosis and the clinical characteristics.

Then, the probability equation for a CN participant to convert to $\mathrm{MCI}$ is as follows: $\mathrm{P}(\mathrm{MCI})=1 /\left(1+\mathrm{e}^{-\mathrm{I}-}\right.$ $0.153 * \mathrm{X}_{1}-0.194 * \mathrm{X}_{2}{ }^{-50786.249 * \mathrm{X}_{3}-18793.242 * \mathrm{X}_{4}+30.892}$ ) where $\mathrm{e}=2,71828$ (the base of natural logarithm), $\mathrm{X}_{1}=$ Age, $\mathrm{X}_{2}=$ the semantic lexical evocation for "vegetables" performance, $\mathrm{X}_{3}=$ the right subiculum body volume, $\mathrm{X}_{4}=$ the left medial pulvinar thalamic nucleus volume, and 30.892 is the model's constant. The models were characterized by a sensitivity and specificity of $6.7 \%$ and $99.4 \%$ a (Table 5), positive and negative predictive values were $50 \%$ and $92.35 \%$. Yule Q coefficient was 0.85 indicating a very strong link between the diagnosis and the clinical characteristics (Tables 4, 5).

\section{Discussion}

Our results show that (1) participants with $\mathrm{MCI}$ and $\mathrm{CN}$ who maintain their cognitive performance at the 4 years follow-up, tend to exhibited (i) a lower NPS prevalence, (ii) a higher cognitive performance and (iii) a lower number of involved brain structures; (2) from all NPS, only the presence of agitation might have the highest potential of predicting MCI participants who might convert in AD over 4 years; (2) from all cognitive performance tests, only poorer mnesic performances seems to predict MCIs who convert to $\mathrm{AD}$ over 4 years, and only language performance might predict $\mathrm{CN}$ who convert to $\mathrm{MCI}$ over 4 years; (3) brain regions that seem to have the highest relevance in predicting conversion over 4 years, seem to be the hippocampus, amygdala, temporal inferior and parietal precuneus in the case of MCI participants, and hippocampus and thalamus in the case of Cn participants.

The involvement of agitation in our prediction model and absence of other NPS is of particular interest. Indeed, agitation along with appetite changes first appeared to have a significant higher prevalence in 
medRxiv preprint doi: https://doi.org/10.1101/2021.12.01.21267124; this version posted December $2,2021$. The copyright holder for this preprint (which was not certified by peer review) is the author/funder, who has granted medRxiv a license to display the preprint in All rights reserved. No reuse allowed without permission.

the MCI-converted group. Previous studies also outlined this potential trend by reporting agitation a precursor to future AD development (Gallagher et al. 2017; Lü et al. 2021; Rosenberg et al. 2013; Teng et al. 2007) and a sign in MCI participants that would correspond to an early AD diagnosis (Geda et al. 2014). Yet no specific link was reported regarding appetite changes. Furthermore, the involvement of other NPS has been reported: depression, anxiety, apathy, irritability, psychotic symptoms. Though in our model these NPS did not survive the significant threshold for the prevalence, nor did they appear in the prediction model, they did show a non-significant up to double increase in prevalence. This inconsistency might be due to (i) a difference in the NPS included in the model, (ii) significant difference in the number of participants as well as (iii) too high constraints used in our study. We would also outline the potential difference in the results regarding the involvement of NPS in the conversion of $\mathrm{CN}$ to MCI. Whereas several studies have been able to describe that the presence of NPS in CN increased the risk of conversion to MCI (Mortby et al. 2018; Lee et al. 2012, Steenland et al. 2012; van Dalen et al. 2018; Gallagher et al. 2011), our results found only an increased prevalance of anxiety and nighttime behavior changes in the $\mathrm{CN}$-converted group in comparison to $\mathrm{CN}$-non-converted, and yet, this increased prevalence didn't seem to have a high potential for prediction. Nevertheless, this particular result we report only as a trend, due to the low number of $\mathrm{CN}$-converted participants.

Cognitively, our results show lower verbal mnesic performance and semantic lexical evocation in MCIconverted vs. MCI-non-converted. Interestingly, we do not find executive weaknesses in MCIconverted although these deficits are frequent in MCI in relation to NPS (Rosenberg et al. 2011) as well as in $\mathrm{AD}$ (Grober et al. 2009). In addition, mnesic difficulties occur much earlier than the diagnosis of $\mathrm{AD}$ in comparison to executive difficulties (Grober et al. 2009). The CN-converted vs. CN-nonconverted showed worse verbal mnesic, working memory and semantic lexical evocation performance. These performances cannot be considered as deficits in $\mathrm{CN}$ participants (because their performance remains within the populational norms established by the standardization of the tests), but they can probably be cognitive fragilities and signs of a beginning of cognitive decline, potentially in line with subjective cognitive complaints, not objectified by the neuropsychological tests (Edmonds et al. 2014; Mitchell et al. 2014; van Oijen et al. 2007). As such, only memory and semantic lexical evocation 
medRxiv preprint doi: https://doi.org/10.1101/2021.12.01.21267124; this version posted December $2,2021$. The copyright holder for this preprint (which was not certified by peer review) is the author/funder, who has granted medRxiv a license to display the preprint in All rights reserved. No reuse allowed without permission.

remained significantly involved in predicting conversion to $\mathrm{AD}$ and to $\mathrm{MCI}$ in our logistic regression models.

Regarding the significant role of memory performance, this is in line with the results of Baerresen et al. (2015). The use of this type of model, with predictive purposes, is more frequent in recent years and could be applied in individuals with non-amnestic MCI (San Lee et al. 2018), MCI due to Parkinson's disease (Chen et al. 2020) or even multiple sclerosis (Eijlers et al. 2018). Unfortunately, these studies do not systematically mention the reliability criteria of their models.

Concerning brain difference between MCI-converted and MCI-non-converted, brain characteristics were broader and involve cortical structures of all lobes and subcortical regions of the hippocampus and amygdala. This suggests that diffuse cerebral frailties may already be present at the MCI stage, prior to the diagnosis of $\mathrm{AD}$. However, only left precuneus, right temporal inferior, right hippocampus and right amygdala remained significantly predictive of conversion in the logistic regression model. Other studies have also shown cortical thinning of several lobes in MCI patients and even more so in AD, with a more important involvement of the left hemisphere (Singh et al. 2006; Wang et al. 2009). This asymmetry is also found in our data.

When analyzing specific brain changes from the perspective of involved NPS (agitation and appetite changes) and their potential to influence the brain in MCI-converted participants, previous studies showed that agitation was characterized by insular, superior frontal, middle, orbital, parieto-occipital, hippocampal, and amygdala atrophies in MCI (Hsu et al. 2015; Hu et al. 2015; Trzepacz et al.., 2013). Furthermore, these atrophies were broadly similar between MCI and AD patients. Our data comparing the effect of agitation in converters and non-converters instead showed occipital, cingulate, precentral, superior temporal, parasubiculum, and amygdala features. Note that the impact of agitation in nonconverters was characterized mainly by reductions in structure size, and by increases in size in converters. This might suggest that the underlying physiological processes are not the same (e.g. atrophy vs. compensation or inflammation). According to Bateman et al. (2020), pro-inflammatory processes have a positive correlation with agitation in $\mathrm{AD}$ while anti-inflammatory processes have a negative correlation with agitation. Since the increase in brain structures here is only observed in our 
medRxiv preprint doi: https://doi.org/10.1101/2021.12.01.21267124; this version posted December $2,2021$. The copyright holder for this preprint (which was not certified by peer review) is the author/funder, who has granted medRxiv a license to display the preprint in All rights reserved. No perpetuity.

converted group, we should look at the age of the agitation. It could be assumed that in the converted group, agitation is older and could have allowed the development of inflammatory processes.

Interestingly, appetite changes seem more prevalent in MCI converted in AD than in non-converted but them were not retained by regression models as significant factor who predict the conversion. Frequently, these behavioral changes are mainly associated with posterior structures. Particularly, them have been described in patients with posterior cortical atrophy but associated with posterior structures also in typical AD (Isella et al. 2015), indicating that posterior brain damage is not specific to these disorders. Overall, these are understudied disorders and often dependent on other NPS such as anxiety or depression (Ismail et al. 2008; Suma et al. 2018). This makes these disorders more complicated to study, especially on a neuroanatomical level.

In the $\mathrm{CN}$ to $\mathrm{MCI}$ conversion, the poorer performance in memory suggested that the brain structures involved in memory would be reduced in people who convert to MCI. However, the cortical and subcortical structures involved appear to be broader and involved in emotional (cingular, amygdala, frontal orbital), memory (temporal, hippocampus) and multimodal functions (thalamus). According to regression model, smaller volumes in the right hippocampus and the left thalamus predicted better the conversion to MCI. Previous studies that have looked at brain differences have focused on comparisons between CN individuals and individuals with MCI. These studies showed reductions in hippocampal, entorhinal and parahippocampal cortex volumes (Jessen et al. 2006; Saykin et al. 2006). In their study Gifford et al. (2015) compared patients with MCI with vs. without subjective memory complaints (SMC). Their results show lower performance in immediate and delayed episodic memory assessed on a serial list learning task in individuals with subjective memory complaints, but no difference in volumes and thicknesses of brain regions of interest (lobar volumes: frontal, parietal, temporal, cingulate; and specific medial temporal lobe structures: hippocampal volume, entorhinal cortex thickness, parahippocampal gyrus thickness). In addition, Schultz et al. (2015) studied cognitively normal subjects with vs. without SMC. Their results showed that, compared with individuals without SMC, those with SMC had significant cortical thinning in the entorhinal, fusiform, posterior cingulate, and inferior parietal cortices and significantly reduced amygdala volume. Similarly, those with SMC had significantly lower test scores on measures of Immediate Memory, Verbal Learning \& Memory, 
medRxiv preprint doi: https://doi.org/10.1101/2021.12.01.21267124; this version posted December $2,2021$. The copyright holder for this preprint (which was not certified by peer review) is the author/funder, who has granted medRxiv a license to display the preprint in All rights reserved. No reuse allowed without permission.

and Verbal Ability (Schultz et al. 2015). One explanation from Gifford et al (2015) about their absence of brain differences between MCI with vs without SMC is that null finding could suggest that MCI individuals who report a memory change have medial temporal and global atrophy comparable to MCI individuals who deny any memory changes, making detection of any between-group differences difficult. Other studies, conducted in a large community-based sample, SMC were associated with cross-sectional decrements in hippocampal, parahippocampal, and amygdala volumes (Stewart et al. 2008) and longitudinal hippocampal volume loss 4 years later (Stewart et al. 2011).

To our knowledge, most studies have focused on regions of interest known to be involved in Alzheimer's disease, whereas our study looked at the entire cortex and subcortical structures. Furthermore, our results may suggest brain changes that precede medial temporal damage, which is usually considered as an anatomical precursor of cognitive decline due to Alzheimer's disease.

Because the risk of developing MCI was dependent on certain demographic data, we chose to include them in the regression model, whereas these variables were controlled in the ANCOVA model to isolate differences related to cognitive performance and brain structure size. Other analyses, on other databases, should also consider the systematic presence of SMC in CN individuals, as well as the presence of symptoms related to awareness of changes and difficulties (anosognosia and/or anosodiaphoria). Alternatively, if our results do not show neuropsychiatric differences in $\mathrm{CN}$-converted, this may suggest the existence of "subjective behavioral complaints" that would precede the objectification of a mild behavioral disorder, as described by Ismail et al. (2016, 2017), in analogy to the stages of cognitive decline model.

One limitation of this study concerns the small proportion of $\mathrm{CN}$ individuals who convert to $\mathrm{MCI}$. Several factors could explain this low rate as well as the lack of NPS involvement in conversion to MCI: 1) many participants were not followed up due to dropout (significant attrition), 2) the presence of NPS increases the risk of stopping participation in database follow-up, this risk induces a selectivity bias of a lower proportion of longitudinal data in participants with NPS (Burke et al. 2019), 3) other factors increase attrition (older age, lower education and socioeconomic level)(Bhamra et al. 2008). This could explain the low sensitivity of our model. Furthermore, the presence of NPS is considered a risk factor for cognitive decline, not a necessary condition for decline. Thus, subgroups of individuals 
medRxiv preprint doi: https://doi.org/10.1101/2021.12.01.21267124; this version posted December $2,2021$. The copyright holder for this preprint (which was not certified by peer review) is the author/funder, who has granted medRxiv a license to display the preprint in

All rights reserved. No reuse allowed without permission.

developing MCI without NPS can frequently be observed. Finally, the limited implication of neuromorphological characteristics may have reduced the possibility of distinguishing our two subgroups. Indeed, some data appear to support cerebral metabolic abnormalities in the preclinical stages of AD rather than structural abnormalities (Kljajevic et al. 2014; $\mathrm{Ng}$ et al. 2017).

\section{Conclusion}

Research on the preclinical stages of $\mathrm{AD}$ is frequent and focuses on different diagnostic criteria and risk factors. As far as we know, our study is one of the first to apply these types of models with MCI and $\mathrm{CN}$ individuals using both neuropsychiatric, cognitive and neuromorphological data. Weproposed to distinguish $\mathrm{MCI}$ and $\mathrm{CN}$ participants who convert to $\mathrm{AD}$ and $\mathrm{MCI}$, respectively, after 4 years of followup from the ADNI database. We were able to establish two predictive models to distinguish participants evolving to a more severe clinical stage. The conversion from MCI to AD was characterized by the presence of agitation, lower memory performance and smaller volumes of inferior temporal, hippocampal and amygdala brain structures, whereas the conversion from $\mathrm{CN}$ to $\mathrm{MCI}$ was characterized by lower performance on semantic evocation and smaller volumes of hippocampal and thalamic brain structures. The use of these analytical methods might be a good way to anticipate cognitive and brain declines. 
medRxiv preprint doi: https://doi.org/10.1101/2021.12.01.21267124; this version posted December $2,2021$. The copyright holder for this preprint (which was not certified by peer review) is the author/funder, who has granted medRxiv a license to display the preprint in All rights reserved. No reuse allowed without permission.

\section{Acknowledgements}

\section{Funding}

This work was supported by the doctoral research scholarship Centre de Recherche de l'Institut Universitaire de Gériatrie Montréal (CRIUGM)-Volet B in collaboration with NiEmoLab and a Faculty of Medicine of the Université de Montréal merit scholarship in collaboration with NiEmoLab to LR; also funding from the Parkinson Canada-Parkinson Quebec (2018-00355), IUGM Foundation, Fonds de Recherche du Québec Santé, Lemaire Foundation to AH.

\section{Use of ADNI data}

Data collection and sharing for this project was funded by the Alzheimer's Disease Neuroimaging Initiative (ADNI) (National Institutes of Health Grant UO1 AG024904) and DOD ADNI (Department of Defense award number W81XWH-12-2-0012). ADNI is funded by the National Institute on Aging, the National Institute of Biomedical Imaging and Bioengineering, and through generous contributions from the following: AbbVie, Alzheimer's Association; Alzheimer's Drug Discovery Foundation; Araclon Biotech; BioClinica, Inc.; Biogen; Bristol-Myers Squibb Company; CereSpir, Inc.; Cogstate; Eisai Inc.; Elan Pharmaceuticals, Inc.; Eli Lilly and Company; EuroImmun; F. Hoffmann-La Roche Ltd and its affiliated company Genentech, Inc.; Fujirebio; GE Healthcare; IXICO Ltd.; Janssen Alzheimer Immunotherapy Research \& Development, LLC.; Johnson \& Johnson Pharmaceutical Research \& Development LLC.; Lumosity; Lundbeck; Merck \& Co., Inc.; Meso Scale Diagnostics, LLC.; NeuroRx Research; Neurotrack Technologies; Novartis Pharmaceuticals Corporation; Pfizer Inc.; Piramal Imaging; Servier; Takeda Pharmaceutical Company; and Transition Therapeutics. The Canadian Institutes of Health Research is providing funds to support ADNI clinical sites in Canada. Private sector contributions are facilitated by the Foundation for the National Institutes of Health (www.fnih.org). The grantee organization is the Northern California Institute for Research and Education, and the study is coordinated by the Alzheimer's Therapeutic Research Institute at the University of Southern California. ADNI data are disseminated by the Laboratory for NeuroImaging at the University of Southern California.

\section{Competing interests}

The authors report no competing interests. 
medRxiv preprint doi: https://doi.org/10.1101/2021.12.01.21267124; this version posted December $2,2021$. The copyright holder for this preprint (which was not certified by peer review) is the author/funder, who has granted medRxiv a license to display the preprint in

All rights reserved. No reuse allowed without permission.

\section{References}

Albert MS, DeKosky ST, Dickson D, Dubois B, Feldman HH, Fox NC, Gamst A, Holtzman DM, Jagust WJ, Petersen RC, Snyder PJ, Carrillo MC, Thies B, Phelps CH. 2011. The diagnosis of mild cognitive impairment due to Alzheimer's disease: recommendations from the National Institute on AgingAlzheimer's Association workgroups on diagnostic guidelines for Alzheimer's disease. Alzheimers Dement. 7:270-9.

American Psychiatric Association. 2013. Diagnostic and statistical manual of mental disorders: DSM5. Arlington, VA.

Baerresen KM, Miller KJ, Hanson ER, Miller JS, Dye RV, Hartman RE, Vermeersch D, Small GW. 2015. Neuropsychological tests for predicting cognitive decline in older adults. Neurodegener Dis Manag. 5:191-201.

Bateman DR, Gill S, Hu S, Foster ED, Ruthirakuhan MT, Sellek AF, Mortby ME, Matušková V, Ng KP, Tarawneh RM, Freund-Levi Y, Kumar S, Gauthier S, Rosenberg PB, Ferreira de Oliveira F, Devanand DP, Ballard C, Ismail Z, International Society to Advance Alzheimer's Research and Treatment (ISTAART), Neuropsychiatric Syndromes Professional Interest Area (NPS-PIA). 2020. Agitation and impulsivity in mid and late life as possible risk markers for incident dementia. Alzheimers Dement (N Y). 6:e12016.

Bednarek A, Mojs E, Krawczyk-Wasielewska A, Głodowska K, Samborski W, Lisiński P, Kopczyński P, Gregersen R, Millán-Calenti JC. 2016. Correlation between depression and burden observed in informal caregivers of people suffering from dementia with time spent on caregiving and dementia severity. Eur Rev Med Pharmacol Sci. 20:59-63.

Bhamra S, Tinker A, Mein G, Ashcroft R, Askham J. 2008. The retention of older people in longitudinal studies: a review of the literature. Quality in Ageing and Older Adults. 9:27-35.

Burhanullah MH, Tschanz JT, Peters ME, Leoutsakos JM, Matyi J, Lyketsos CG, Nowrangi MA, Rosenberg PB. 2020. Neuropsychiatric Symptoms as Risk Factors for Cognitive Decline in Clinically Normal Older Adults: The Cache County Study. The American journal of geriatric psychiatry : official journal of the American Association for Geriatric Psychiatry. 28:64-71. 
medRxiv preprint doi: https://doi.org/10.1101/2021.12.01.21267124; this version posted December $2,2021$. The copyright holder for this preprint (which was not certified by peer review) is the author/funder, who has granted medRxiv a license to display the preprint in All rights reserved. No reuse allowed without permission.

Burke SL, Hu T, Naseh M, Fava NM, O'Driscoll J, Alvarez D, Cottler LB, Duara R. 2019. Factors influencing attrition in 35 Alzheimer's Disease Centers across the USA: a longitudinal examination of the National Alzheimer's Coordinating Center's Uniform Data Set. Aging Clin Exp Res. 31:1283-1297. Chen PH, Cheng FY, Cheng SJ, Shaw JS. 2020. Predicting Cognitive Decline in Parkinson's Disease with Mild Cognitive Impairment: A One-Year Observational Study. Parkinsons Dis. 28:8983960.

Creese B, Brooker H, Ismail Z, Wesnes KA, Hampshire A, Khan Z, Megalogeni M, Corbett A, Aarsland D, Ballard C. 2019. Mild Behavioral Impairment as a Marker of Cognitive Decline in Cognitively Normal Older Adults. Am J Geriatr Psychiatry. 27:823-834.

Csukly G, Sirály E, Fodor Z, Horváth A, Salacz P, Hidasi Z, Csibri É, Rudas G, Szabó Á. 2016. The Differentiation of Amnestic Type MCI from the Non-Amnestic Types by Structural MRI. Front Aging Neurosci. 8:52.

Cummings JL, Mega M, Gray K, Rosenberg-Thompson S, Carusi DA, Gornbein J. 1994. The Neuropsychiatric Inventory: comprehensive assessment of psychopathology in dementia. Neurology. 44:2308-14.

Davatzikos C, Bhatt P, Shaw LM, Batmanghelich KN, Trojanowski JQ. 2011. Prediction of MCI to AD conversion, via MRI, CSF biomarkers, and pattern classification. Neurobiol Aging. 32:2322.e19-27. Destrieux C, Fischl B, Dale A, Halgren E. 2010. Automatic parcellation of human cortical gyri and sulci using standard anatomical nomenclature. Neuroimage. 53:1-15.

deToledo-Morrell L, Stoub TR, Bulgakova M, Wilson RS, Bennett DA, Leurgans S, Wuu J, Turner DA. 2004. MRI-derived entorhinal volume is a good predictor of conversion from MCI to AD. Neurobiol Aging. 25:1197-1203.

Devier DJ, Pelton GH, Tabert MH, Liu X, Cuasay K, Eisenstadt R, Marder K, Stern Y, Devanand DP. 2009. The impact of anxiety on conversion from mild cognitive impairment to Alzheimer's disease. Int J Geriatr Psychiatry. 24:1335-1342.

Edmonds EC, Delano-Wood L, Galasko DR, Salmon DP, Bondi MW, Alzheimer's Disease Neuroimaging Initiative. 2014. Subjective cognitive complaints contribute to misdiagnosis of mild cognitive impairment. J Int Neuropsychol Soc. 20:836-847. 
medRxiv preprint doi: https://doi.org/10.1101/2021.12.01.21267124; this version posted December $2,2021$. The copyright holder for this preprint (which was not certified by peer review) is the author/funder, who has granted medRxiv a license to display the preprint in All rights reserved. No reuse allowed without permission.

Eijlers AJC, van Geest Q, Dekker I, Steenwijk MD, Meijer KA, Hulst HE, Barkhof F, Uitdehaag BMJ, Schoonheim MM, Geurts JJG. 2018. Predicting cognitive decline in multiple sclerosis: a 5-year followup study. Brain. 141:2605-2618.

Gallagher D, Coen R, Kilroy D, Belinski K, Bruce I, Coakley D, Walsh B, Cunningham C, Lawlor BA. 2011. Anxiety and behavioural disturbance as markers of prodromal Alzheimer's disease in patients with mild cognitive impairment. Int. J. Geriatr. Psychiatry. 26:166-172.

Gallagher D, Fischer CE, Iaboni A. 2017. Neuropsychiatric symptoms in mild cognitive impairment: an update on prevalence, mechanisms, and clinical significance. The Canadian Journal of Psychiatry. 62:161-169.

Geda YE, Smith GE, Knopman DS, Boeve BF, Tangalos EG, Ivnik RJ, Mrazek DA, Edland SD, Petersen RC. 2004. De novo genesis of neuropsychiatric symptoms in mild cognitive impairment (MCI). Int Psychogeriatr. 16:51-60.

Geda YE, Roberts RO, Knopman DS, Petersen RC, Christianson TJ, Pankratz VS, Smith GE, Boeve BF, Ivnik RJ, Tangalos EG, Rocca WA. 2008. Prevalence of neuropsychiatric symptoms in mild cognitive impairment and normal cognitive aging: population-based study. Arch Gen Psychiatry. 65:1193-1198.

Geda YE, Roberts RO, Mielke MM, Knopman DS, Christianson TJ, Pankratz VS, Boeve BF, Sochor O, Tangalos EG, Petersen RC, Rocca WA. 2014. Baseline neuropsychiatric symptoms and the risk of incident mild cognitive impairment: a population-based study. Am J Psychiatry. 171:572-81.

Gifford KA, Liu D, Damon SM, Chapman WG 4th, Romano Iii RR, Samuels LR, Lu Z, Jefferson AL, Alzheimer's Disease Neuroimaging Initiative. 2015. Subjective memory complaint only relates to verbal episodic memory performance in mild cognitive impairment. J Alzheimers Dis. 44:309-318.

Grober E, Hall CB, Lipton RB, Zonderman AB, Resnick SM, Kawas C. 2008. Memory impairment, executive dysfunction, and intellectual decline in preclinical Alzheimer's disease. J Int Neuropsychol Soc. 14:266-278.

Heidebrink JL. 2002. Is dementia with Lewy bodies the second most common cause of dementia?. Journal of geriatric psychiatry and neurology. 15:182-187. 
medRxiv preprint doi: https://doi.org/10.1101/2021.12.01.21267124; this version posted December $2,2021$. The copyright holder for this preprint (which was not certified by peer review) is the author/funder, who has granted medRxiv a license to display the preprint in All rights reserved. No reuse allowed without permission.

Hsu JL, Lee WJ, Liao YC, Lirng JF, Wang SJ, Fuh JL. 2015. Posterior Atrophy and Medial Temporal Atrophy Scores Are Associated with Different Symptoms in Patients with Alzheimer's Disease and Mild Cognitive Impairment. PLoS One. 10:e0137121.

Hu X, Meiberth D, Newport B, Jessen F, the ADNI. 2015. Anatomical Correlates of the Neuropsychiatric Symptoms in Alzheimer's Disease. Current Alzheimer Research. 12:266-277. Iglesias JE, Augustinack JC, Nguyen K, Player CM, Player A, Wright M, Roy N, Frosch MP, McKee AC, Wald LL, Fischl B, Van Leemput K, Alzheimer's Disease Neuroimaging Initiative. 2015. A computational atlas of the hippocampal formation using ex vivo, ultra-high resolution MRI: Application to adaptive segmentation of in vivo MRI. Neuroimage. 115:117-137.

Iglesias JE, Insausti R, Lerma-Usabiaga G, Bocchetta M, Van Leemput K, Greve DN, van der Kouwe A; Alzheimer's Disease Neuroimaging Initiative, Fischl B, Caballero-Gaudes C, Paz-Alonso PM. 2018. A probabilistic atlas of the human thalamic nuclei combining ex vivo MRI and histology. Neuroimage. $183: 314-326$.

Isella V, Villa G, Mapelli C, Ferri F, Appollonio IM, Ferrarese C. 2015. The neuropsychiatric profile of posterior cortical atrophy. J Geriatr Psychiatry Neurol. 28:136-144.

Ismail Z, Herrmann N, Rothenburg LS, Cotter A, Leibovitch FS, Rafi-Tari S, Black SE, Lanctôt KL. 2008. A functional neuroimaging study of appetite loss in Alzheimer's disease. J Neurol Sci. 271:97103.

Ismail Z, Smith EE, Geda Y, Sultzer D, Brodaty H, Smith G, Agüera-Ortiz L, Sweet R, Miller D, Lyketsos CG, ISTAART Neuropsychiatric Symptoms Professional Interest Area. 2016. Neuropsychiatric symptoms as early manifestations of emergent dementia: Provisional diagnostic criteria for mild behavioral impairment. Alzheimers Dement. 12:195-202.

Ismail Z, Agüera-Ortiz L, Brodaty H, Cieslak A, Cummings J, Fischer CE, Gauthier S, Geda YE, Herrmann N, Kanji J, Lanctôt KL, Miller DS, Mortby ME, Onyike CU, Rosenberg PB, Smith EE, Smith GS, Sultzer DL, Lyketsos C, NPS Professional Interest Area of the International Society of to Advance Alzheimer's Research and Treatment (NPS-PIA of ISTAART). 2017. The Mild Behavioral Impairment Checklist (MBI-C): A Rating Scale for Neuropsychiatric Symptoms in Pre-Dementia Populations. J Alzheimers Dis. 56:929-938. 
medRxiv preprint doi: https://doi.org/10.1101/2021.12.01.21267124; this version posted December $2,2021$. The copyright holder for this preprint (which was not certified by peer review) is the author/funder, who has granted medRxiv a license to display the preprint in All rights reserved. No reuse allowed without permission.

Jak AJ, Bondi MW, Delano-Wood L, Wierenga C, Corey-Bloom J, Salmon DP, Delis DC. 2009. Quantification of five neuropsychological approaches to defining mild cognitive impairment. Am $\mathbf{J}$ Geriatr Psychiatry.17:368-375.

Jessen F, Feyen L, Freymann K, Tepest R, Maier W, Heun R, Schild HH, Scheef L. 2006. Volume reduction of the entorhinal cortex in subjective memory impairment. Neurobiol Aging. 27:1751-1756. Kljajevic V, Grothe MJ, Ewers M, Teipel S, Alzheimer's Disease Neuroimaging Initiative. 2014. Distinct pattern of hypometabolism and atrophy in preclinical and predementia Alzheimer's disease. Neurobiol Aging. 35:1973-1981.

Krell-Roesch J, Syrjanen JA, Machulda MM, Christianson TJ, Kremers WK, Mielke MM, Knopman DS, Petersen RC, Vassilaki M, Geda YE. 2021. Neuropsychiatric symptoms and the outcome of cognitive trajectories in older adults free of dementia: The Mayo Clinic Study of Aging. Int J Geriatr Psychiatry. 36:1362-1369.

Lee GJ, Lu PH, Hua X, Lee S, Wu S, Nguyen K, Teng E, Leow AD, Jack CR Jr, Toga AW, Weiner MW, Bartzokis G, Thompson PM, Alzheimer's Disease Neuroimaging Initiative. 2012. Depressive symptoms in mild cognitive impairment predict greater atrophy in Alzheimer's disease related regions. Biological Psychiatry. 71:814-821.

Lü W, Duan J, Zhang W, Yang W, Yu W. 2021. Relationship between neuropsychiatric symptoms and cognitive functions in patients with cognitive impairment. Psychogeriatrics. 21:773-782.

Ma L. 2020. Depression, Anxiety, and Apathy in Mild Cognitive Impairment: Current Perspectives. Front Aging Neurosci. 12:9.

Mitchell AJ, Beaumont H, Ferguson D, Yadegarfar M, Stubbs B. 2014. Risk of dementia and mild cognitive impairment in older people with subjective memory complaints: meta-analysis. Acta Psychiatr Scand. 130:439-451.

Moon B, Kim S, Park YH, Lim JS, Youn YC, Kim S, Jang JW. 2017. Depressive symptoms are associated with progression to dementia in patients with amyloid-positive mild cognitive impairment. Journal of Alzheimer's Disease. 58:1255-1264. 
medRxiv preprint doi: https://doi.org/10.1101/2021.12.01.21267124; this version posted December $2,2021$. The copyright holder for this preprint (which was not certified by peer review) is the author/funder, who has granted medRxiv a license to display the preprint in All rights reserved. No reuse allowed without permission.

Mortby M, Ismail Z, Anstey K. 2018. Prevalence estimates of mild behavioral impairment in a population-based sample of pre-dementia states and cognitively healthy older adults. Int Psychogeriatr. 30:221-32.

Mueller SG, Weiner MW, Thal LJ, Petersen RC, Jack CR, Jagust W, Trojanowski JQ, Toga AW, Beckett L. 2005. Ways toward an early diagnosis in Alzheimer's disease: the Alzheimer's Disease Neuroimaging Initiative (ADNI). Alzheimers Dement. 1:55-66.

Ng KP, Pascoal TA, Mathotaarachchi S, Chung CO, Benedet AL, Shin M, Kang MS, Li X, Ba M, Kandiah N, Rosa-Neto P, Gauthier S, Alzheimer's Disease Neuroimaging Initiative. 2017. Neuropsychiatric symptoms predict hypometabolism in preclinical Alzheimer disease. Neurology. 88:1814-1821.

Orso B, Mattei C, Arnaldi D, Massa F, Serafini G, Plantone D, Doglione E, Grafman J, Nobili F, Pardini M. 2020. Clinical and MRI Predictors of Conversion From Mild Behavioural Impairment to Dementia. Am J Geriatr Psychiatry. 28:755-763.

Petersen RC, Negash S. 2008. Mild cognitive impairment: an overview. CNS spectrums. 13:45-53.

Risacher SL, Saykin AJ, West JD, Shen L, Firpi HA, McDonald BC, Alzheimer's Disease Neuroimaging Initiative. 2009. Baseline MRI predictors of conversion from MCI to probable AD in the ADNI cohort. Curr Alzheimer Res. 6:347-361.

Rosenberg PB, Mielke MM, Appleby B, Oh E, Leoutsakos JM, Lyketsos CG. 2011. Neuropsychiatric symptoms in MCI subtypes: the importance of executive dysfunction. Int J Geriatr Psychiatry. 26:364372.

Rosenberg PB, Mielke MM, Appleby BS, Oh ES, Geda YE, Lyketsos CG. 2013. The association of neuropsychiatric symptoms in MCI with incident dementia and Alzheimer disease. Am J Geriatr Psychiatry. 21:685-95.

Robert PH, Berr C, Volteau M, Bertogliati-Fileau C, Benoit M, Guerin O, Sarazin M, Legrain S, Dubois B, PréAL Study Group. 2008. Importance of lack of interest in patients with mild cognitive impairment. Am J Geriatr Psychiatry. 16:770-776.

Rozzini L, Chilovi BV, Peli M, Conti M, Rozzini R, Trabucchi M, Padovani A. 2009. Anxiety symptoms in mild cognitive impairment. Int J Geriatr Psychiatry. 24:300- 305. 
medRxiv preprint doi: https://doi.org/10.1101/2021.12.01.21267124; this version posted December $2,2021$. The copyright holder for this preprint (which was not certified by peer review) is the author/funder, who has granted medRxiv a license to display the preprint in All rights reserved. No reuse allowed without permission.

San Lee J, Cho SK, Kim HJ, Kim YJ, Park KC, Lockhart SN, Na DL, Kim C, Seo SW. 2018. Prediction models of cognitive trajectories in patients with nonamnestic mild cognitive impairment. Scientific reports. 8:1-8.

Sanfilipo MP, Benedict RHB, Zivadinov R, Bakshi R. 2004. Correction for intracranial volume in analysis of whole brain atrophy in multiple sclerosis: the proportion vs. residual method. Neuroimage 221732-1743.

Saygin ZM, Kliemann D, Iglesias JE, van der Kouwe AJW, Boyd E, Reuter M, Stevens A, Van Leemput K, McKee A, Frosch MP, Fischl B, Augustinack JC, Alzheimer's Disease Neuroimaging Initiative. 2017. High-resolution magnetic resonance imaging reveals nuclei of the human amygdala: manual segmentation to automatic atlas. Neuroimage. 155:370-382.

Saykin AJ, Wishart HA, Rabin LA, Santulli RB, Flashman LA, West JD, McHugh TL, Mamourian AC. 2006. Older adults with cognitive complaints show brain atrophy similar to that of amnestic MCI. Neurology. 67:834-842.

Schultz SA, Oh JM, Koscik RL, Dowling NM, Gallagher CL, Carlsson CM, Bendlin BB, LaRue A, Hermann BP, Rowley HA, Asthana S, Sager MA, Johnson SC, Okonkwo OC. 2015. Subjective memory complaints, cortical thinning, and cognitive dysfunction in middle-aged adults at risk for AD. Alzheimers Dement (Amst). 1:33-40.

Schulz R, McGinnis KA, Zhang S, Martire LM, Hebert RS, Beach SR, Zdaniuk B, Czaja SJ, Belle SH. 2008. Dementia patient suffering and caregiver depression. Alzheimer Dis Assoc Disord. 22:170-6.

Shaw LM, Korecka M, Clark CM, Lee VM, Trojanowski JQ. 2007. Biomarkers of neurodegeneration for diagnosis and monitoring therapeutics. Nat Rev Drug Discov.6:295-303.

Steenland K, Karnes C, Seals R, Carnevale C, Hermida A, Levey A. 2012. Late-life depression as a risk factor for mild cognitive impairment or Alzheimer's disease in 30 US Alzheimer's disease centers. J. Alzheimers Dis. 31:265-275.

Stewart R, Dufouil C, Godin O, Ritchie K, Maillard P, Delcroix N, Crivello F, Mazoyer B, Tzourio C. 2008. Neuroimaging correlates of subjective memory deficits in a community population. Neurology. 70:1601-1607. 
medRxiv preprint doi: https://doi.org/10.1101/2021.12.01.21267124; this version posted December $2,2021$. The copyright holder for this preprint (which was not certified by peer review) is the author/funder, who has granted medRxiv a license to display the preprint in All rights reserved. No reuse allowed without permission.

Stewart R, Godin O, Crivello F, Maillard P, Mazoyer B, Tzourio C, Dufouil C. 2011. Longitudinal neuroimaging correlates of subjective memory impairment: 4-year prospective community study. The British Journal of Psychiatry. 198:199-205.

Suma S, Watanabe Y, Hirano H, Kimura A, Edahiro A, Awata S, Yamashita Y, Matsushita K, Arai H, Sakurai T. 2018. Factors affecting the appetites of persons with Alzheimer's disease and mild cognitive impairment. Geriatr Gerontol Int. 18:1236-1243.

Teng E, Lu PH, Cummings JL. 2007. Neuropsychiatric symptoms are associated with progression from mild cognitive impairment to Alzheimer's disease. Dementia and geriatric cognitive disorders. 24:253259.

Trzepacz PT, Yu P, Bhamidipati PK, Willis B, Forrester T, Tabas L, Schwarz AJ, Saykin AJ, Alzheimer's Disease Neuroimaging Initiative. 2013. Frontolimbic atrophy is associated with agitation and aggression in mild cognitive impairment and Alzheimer's disease. Alzheimers Dement. 9:S95S104.e1.

van Dalen JW, van Wanrooij LL, Moll van Charante EP, Brayne C, van Gool WA, Richard E. 2018. Association of apathy with risk of incident dementia: a systematic review and meta-analysis. JAMA Psychiatry. 75:1012-1021.

van Oijen M, de Jong FJ, Hofman A, Koudstaal PJ, Breteler MM. 2007. Subjective memory complaints, education, and risk of Alzheimer's disease. Alzheimers Dement. 3:92-97.

Zahodne LB, Gongvatana A, Cohen RA, Ott BR, Tremont G, Alzheimer's Disease Neuroimaging Initiative. 2013. Are apathy and depression independently associated with longitudinal trajectories of cortical atrophy in mild cognitive impairment?. The American Journal of Geriatric Psychiatry. 21:10981106. 
medRxiv preprint doi: https://doi.org/10.1101/2021.12.01.21267124; this version posted December 2, 2021 . The copyright holder for this preprint (which was not certified by peer review) is the author/funder, who has granted medRxiv a license to display the preprint in perpetuity.

All rights reserved. No reuse allowed without permission.

\section{Tables}

Table 1: Demographic, neuropsychiatric and neuropsychological characteristics for $\mathrm{MCI}$ and $\mathrm{CN}$ groups (non-converted and converted).

\begin{tabular}{|c|c|c|c|c|c|c|c|c|}
\hline & \multicolumn{4}{|c|}{ MCI } & \multicolumn{4}{|c|}{$\mathbf{C N}$} \\
\hline & Non- & Converted & T/Chi' & $\mathbf{P}$ & Non-converted & Converted & T/Chi' & $\mathbf{p}$ \\
\hline & converted & & & & & & & \\
\hline $\mathbf{N}$ & 156 & 119 & & & 170 & 15 & & \\
\hline \multicolumn{9}{|c|}{ Demographic (mean/sd) } \\
\hline Age & $75.07 / 7.75$ & $74.54 / 7.52$ & 0.572 & 0.568 & $75.4 I / 4.92$ & $74.00 / 5.28$ & 1.06 & 0.291 \\
\hline Education & I5.55/3.07 & $|5.93 / 2.8|$ & -1.060 & 0.290 & $16.15 / 2.81$ & $16.07 / 2.84$ & 0.114 & 0.909 \\
\hline Sex (\% women) & 39.1 & 35.3 & 0.418 & 0.518 & 48.8 & 40 & 0.430 & 0.512 \\
\hline MMSE & $27.51 / 1.73$ & $26.87 / 1.67$ & 3.125 & 0.002 & $29.12 / 1.00$ & $28.67 / 1.50$ & 1.598 & 0.112 \\
\hline \multicolumn{9}{|l|}{ NPS (\%) } \\
\hline Delusion & 0 & 0.8 & 1.316 & 0.251 & 0 & 0 & - & - \\
\hline Hallucination & 0 & 0.8 & 1.316 & $0.25 I$ & 0.6 & 0 & 0.089 & 0.766 \\
\hline Agitation & 12.8 & 26.9 & 8.716 & 0.003 & 3.5 & 0 & 0.547 & 0.459 \\
\hline Depression & 14.7 & 21.8 & 2.327 & 0.127 & 4.7 & 0 & 0.738 & 0.390 \\
\hline Anxiety & 16.0 & 21.0 & 1.127 & 0.288 & 3.5 & 6.7 & 0.373 & 0.542 \\
\hline Euphoria & 3.2 & 3.4 & 0.005 & 0.942 & 0 & 0 & - & - \\
\hline Apathy & 10.9 & 15.1 & 1.087 & 0.297 & 1.8 & 0 & 0.269 & 0.604 \\
\hline Disinhibition & 5.1 & 9.2 & $\mathrm{I} .778$ & 0.182 & 0.6 & 0 & 0.089 & 0.766 \\
\hline Irritability & 27.6 & 30.3 & 0.238 & 0.625 & 7.1 & 6.7 & 0.003 & 0.955 \\
\hline AMB & 4.5 & 4.2 & 0.013 & 0.909 & 0.6 & 0 & 0.089 & 0.766 \\
\hline Nighttime behavior & 12.2 & 13.4 & 0.097 & 0.755 & 9.4 & 20 & 1.677 & 0.195 \\
\hline Appetite changes & 7.7 & 15.1 & 3.838 & 0.050 & 0.6 & 0 & 0.089 & 0.766 \\
\hline \multicolumn{9}{|c|}{ Cognitive Assess. (mean/sd) } \\
\hline Clock drawing & $4.43 / 0.76$ & $4.13 / 1.05$ & $2.78 I$ & 0.008 & $4.7 I / 0.59$ & $4.60 / 0.74$ & 0.650 & 0.516 \\
\hline Clock copy & $4.76 / 0.49$ & $4.61 / 0.69$ & 1.924 & 0.056 & $4.89 / 0.35$ & $4.67 / 0.82$ & $\mathrm{I} .043$ & 0.314 \\
\hline RAVLT I & $4.62 / 1.64$ & $3.76 / 1.26$ & 4.902 & 0.000 & $5.18 / 1.61$ & $4.73 / 1.03$ & $\mathrm{I} .047$ & 0.296 \\
\hline RAVLT 2 & $6.10 / 2.06$ & $5.00 / 1.48$ & 5.173 & 0.000 & $7.72 / 1.97$ & $6.60 / 1.18$ & 2.162 & 0.032 \\
\hline RAVLT 3 & $7.24 / 2.32$ & $5.90 / 1.53$ & 5.781 & 0.000 & $9.44 / 2.32$ & $8.53 / 2.59$ & 1.429 & 0.155 \\
\hline RAVLT 4 & $7.77 / 2.54$ & $6.27 / 1.54$ & 6.052 & 0.000 & $10.54 / 2.38$ & $9.33 / 2.61$ & 1.860 & 0.065 \\
\hline RAVLT 5 & $8.47 / 2.67$ & $6.64 / 2.00$ & 6.514 & 0.000 & $\mathrm{II} .18 / 2.24$ & $10.53 / 2.62$ & $\mathrm{I} .06 \mathrm{I}$ & 0.290 \\
\hline RAVLT 6 & $4.79 / 3.58$ & $2.55 / 2.08$ & 6.511 & 0.000 & $8.39 / 3.44$ & $7.07 / 2.63$ & 1.456 & 0.147 \\
\hline RAVLT B & $3.96 / 1.59$ & $3.40 / 1.32$ & 3.103 & 0.002 & $5.05 / 1.68$ & $4.87 / 2.80$ & 0.386 & 0.700 \\
\hline DS Forward & $8.34 / 2.06$ & $8.32 / 1.99$ & 0.083 & 0.934 & $8.88 / 2.02$ & $8.13 / 1.96$ & 1.378 & 0.170 \\
\hline
\end{tabular}


medRxiv preprint doi: https://doi.org/10.1101/2021.12.01.21267124; this version posted December $2,2021$. The copyright holder for this preprint (which was not certified by peer review) is the author/funder, who has granted medRxiv a license to display the preprint in

All rights reserved. No reuse allowed without permission.

\begin{tabular}{|c|c|c|c|c|c|c|c|c|}
\hline DS Backward & $6.4 I / 2.14$ & $6.10 / 1.82$ & 1.296 & 0.196 & $7.25 / 2.17$ & $6.27 / 1.22$ & $1.72 \mathrm{I}$ & 0.087 \\
\hline Animals & $16.52 / 4.68$ & $15.70 / 4.86$ & 1.419 & 0.157 & $20.16 / 5.56$ & $18.73 / 5.84$ & 0.948 & 0.344 \\
\hline Vegetables & $11.64 / 3.38$ & $|0.04 / 3.3|$ & 3.922 & 0.000 & $14.91 / 3.70$ & $12.80 / 3.86$ & 2.114 & 0.036 \\
\hline TMTA & $40.72 / 17.02$ & $48.76 / 26.19$ & -2.912 & 0.004 & $35.91 / 12.97$ & $37.20 / 12.23$ & -0.370 & 0.712 \\
\hline TMTB & $\begin{array}{c}|| 0.3 \mid / 59.4 \\
7\end{array}$ & I43.44/78.24 & -3.848 & 0.000 & $86.12 / 43.96$ & $91.20 / 26.92$ & -0.440 & 0.661 \\
\hline Symbol Digit & $39.75 / 11.00$ & $35.15 / 10.72$ & 3.473 & 0.001 & $46.20 / 10.34$ & $43.47 / 6.96$ & 1.003 & 0.317 \\
\hline BNT & $26.17 / 3.55$ & $25.50 / 3.90$ & $\mathrm{I} .487$ & 0.138 & $27.88 / 2.31$ & $27.80 / 2.18$ & 0.133 & 0.894 \\
\hline RAVLT Del. & $3.90 / 3.70$ & $1.55 / 2.30$ & 6.470 & 0.000 & $7.73 / 3.62$ & $6.07 / 3.67$ & 1.703 & 0.090 \\
\hline RAVLT tot & $10.63 / 3.32$ & $8.58 / 3.83$ & 4.736 & 0.000 & $12.98 / 2.44$ & $12.40 / 2.10$ & 0.886 & 0.377 \\
\hline
\end{tabular}

Legend: $\mathrm{sd}$ = standard deviation, MMSE = MiniMental State Examination, NPS = Neuropsychiatric

Symptoms, RAVLT = Rey Auditory Verbal Learning Test (free recall 1 to 6, list B and delayed), DS =

Digit Span, $\mathrm{TMT}=$ Trail Making Test, $\mathrm{BNT}=$ Boston Naming Test 
medRxiv preprint doi: https://doi.org/10.1101/2021.12.01.21267124; this version posted December 2, 2021. The copyright holder for this preprint (which was not certified by peer review) is the author/funder, who has granted medRxiv a license to display the preprint in

All rights reserved. No reuse allowed without permission.

Table 2: Binary Logistic Regression for the conversion from MCI to AD

\begin{tabular}{rrr} 
Variables & B & Sig. \\
\hline Age & $-0,070$ & 0,003 \\
\hline Free recall I of RAVLT & $-0,275$ & 0,024 \\
Free recall 5 of RAVLT & $-0,233$ & 0,003 \\
\hline Agitation & 0,765 & 0,049 \\
\hline Parietal precuneus gyrus left & $-2,425$ & 0,012 \\
\hline Temporal inferior sulcus right & $-4,026$ & 0,000 \\
\hline Hippocampus tail right & $-10665,677$ & 0,004 \\
\hline Hippocampus fimbria right & $-26915,115$ & 0,044 \\
\hline Amygdala Accessory Basal nucleus right & $-18399,454$ & 0,024 \\
\hline Constante & 28,139 & 0,000 \\
\hline
\end{tabular}


medRxiv preprint doi: https://doi.org/10.1101/2021.12.01.21267124; this version posted December 2, 2021. The copyright holder for this preprint (which was not certified by peer review) is the author/funder, who has granted medRxiv a license to display the preprint in perpetuity.

All rights reserved. No reuse allowed without permission.

Table 3: Psychometric characteristics for regression model of the conversion from MCI to AD

\begin{tabular}{lcccc} 
& & \multicolumn{3}{c}{ Prediction } \\
\cline { 3 - 5 } & & MCI & To AD & Correct Prediction \\
\hline & MCI & 128 & 28 & 82.1 (Spe.) \\
\cline { 2 - 4 } & & 33 & 86 & $72.3($ Sens.) \\
\hline Accuracy & & & 77.8 \\
\hline Positive predictive value & & 75.44 \\
\hline Negative predictive value & & 79.5 \\
\hline Yule Q coefficient & & 0.85
\end{tabular}

Legend: Spe. $=$ Specificity, Sens. $=$ Sensitivity 
medRxiv preprint doi: https://doi.org/10.1101/2021.12.01.21267124; this version posted December 2, 2021. The copyright holder for this preprint (which was not certified by peer review) is the author/funder, who has granted medRxiv a license to display the preprint in All rights reserved. No reuse allowed without permission.

Table 4: Variables significantly involved in predicting conversion from $\mathrm{CN}$ to $\mathrm{MCI}$

\begin{tabular}{rcc} 
Variables & B & Sig. \\
\hline Age & $-0,153$ & 0,027 \\
\hline Semantic lexical evocation « vegetables » & $-0,194$ & 0,036 \\
\hline Hippocampus, subiculum body, right & $-50786,249$ & 0,011 \\
\hline Thalamus, pulvinar medial, left & $-18793,242$ & 0,001 \\
\hline Constante & 30,892 & 0,000
\end{tabular}

Legend: $\mathrm{B}=$ Coefficient from each significative variable, Sig. = Significancy. 
medRxiv preprint doi: https://doi.org/10.1101/2021.12.01.21267124; this version posted December 2, 2021. The copyright holder for this preprint (which was not certified by peer review) is the author/funder, who has granted medRxiv a license to display the preprint in perpetuity.

All rights reserved. No reuse allowed without permission.

Table 5: Psychometric characteristics for regression model of the conversion from $\mathrm{CN}$ to MCI

\begin{tabular}{lcccc} 
& & \multicolumn{3}{c}{ Prediction } \\
\cline { 3 - 5 } & & $\mathbf{C N}$ & To MCl & Correct Prediction \\
\hline Observed & $\mathbf{C N}$ & $\mathrm{I}$ & $99.4($ Spe. $)$ \\
\cline { 2 - 4 } & To MCl & 14 & $\mathrm{I}$ & $6.7($ Sens.) \\
\hline Accuracy & & 91.9 \\
\hline Positive predictive value & & $50 \%$ \\
\hline Negative predictive value & & 92.35 \\
\hline Yule Q coefficient & & 0.85
\end{tabular}

Legend: Spe. $=$ Specificity, Sens. $=$ Sensitivity 